
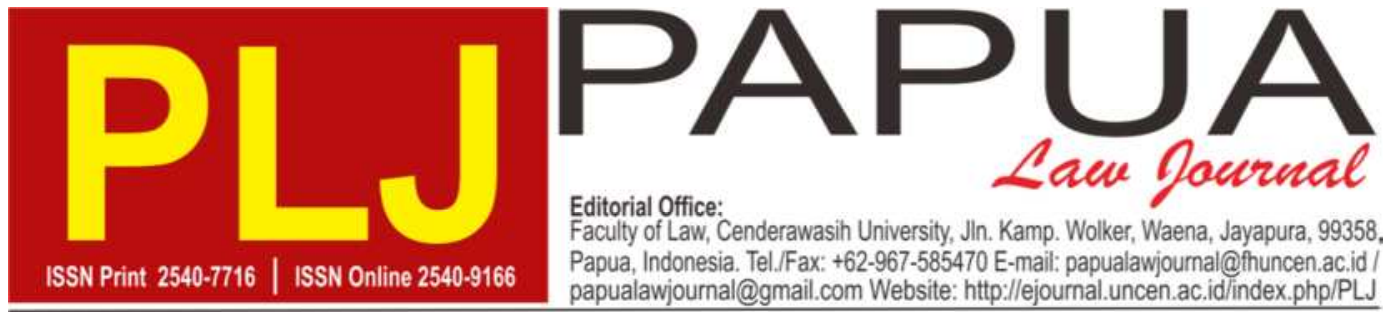

\title{
The Role of Indonesian Police Investigators In Order to Criminal Information and Electronic Transactions in Papua
}

\author{
Tumian Lian Daya Purba \\ Faculty of Law, Cenderawasih University \\ Jl. Kamp Wolker, Waena, Jayapura, 99358, Papua - Indonesia \\ E-mail: tlpurba@gmail.com
}

\begin{abstract}
One part of law enforcement officers who also has an important role for electronic transaction information cases is The Investigator, in this case the investigator is the Republic of Indonesia Police, where investigators are expected to be able to assist the settlement process against of electronic transaction information violations. The object of this article is related to the Role of Indonesia Police Investigators in order to Criminal Information and Electronic Transactions in Papua, it is using normative juridical methods. The results showed that there is a case of electronic information and transactions in 2017 with a sentence of more than five years but no detention. It can be clearly seen that investigators does not pay attention for what will happen to the complainant or witness. And also the investigator has a consideration s that the suspect will not run away and still cooperative.
\end{abstract}

Keywords: Investigator; Crime; Information and Electronic Transactions.

\section{INTRODUCTION}

Indonesia is well-known for the laws that apply to all Indonesians who commit violations, whether the government or public. For the world of information technology and electronics known as the Information and Teachnology Electronic Law (ITE Law). The ITE Law itself was made based on the decision of the board members in 2008. This decision was made based on consensus deliberations to punish violators, especially in the field of electronic technology information.

For cyberspace or better known as cyber, we are increasingly familiar with everyday life among the people of Indonesia. The easiest example is a social networking site that is currently rating very well in the world of friendship, Facebook. In the 
Papua Law Journal — Vol. 2 Issue 2, May 2018

Facebook world itself there are often violations that are blamed by Facebook users themselves which can cause someone's life to disappear. For Facebook users themselves to be made ITE Law No. 19 of 2016, there are three threats brought by the ITE Law that have the potential to overwrite facebook in Indonesia, namely the threat of morality violations (Article 27 paragraph (1)), insult/defamation (Article 27 paragraph (3)) and the spread of hatred based on ethnicity, religion and race is regulated by (Article 28 paragraph (2)). From the ITE law, it can be seen that cyberspace is not as good as we thought, if we use this social network arbitrarily it does not rule out the possibility that we could be charged by the ITE Law with the existing articles Likewise, the implementation of the ITE Law also pays attention to community preparedness, because the ITE Law is the legal umbrella in Indonesia for the first time in the field of Information Technology and Electronic Transactions. The ITE Law has ensnared many users of electronic media, so it is deemed necessary to look at the role of investigators in the
Implementation of Law Number 19 Year 2016 concerning Information and Electronic Transactions against suspects.

One element of law enforcement in Indonesia is the National Police of the Republic of Indonesia, the Police of the Republic of Indonesia (hereinafter abbreviated as Polri) as a state tool as law enforcers are required to be able to carry out professional law enforcement duties in implementing and implementing the rules stipulated in the Law number 19 of 2016 concerning Information and Transactions where the disclosure of cases of electronic transaction information is specific in nature which requires proactive Polri in finding and finding the perpetrators and is always oriented to the capture of perpetrators of criminal acts and the application of legislation in the field of electronic transaction information.

One part of law enforcement officials who also has an important role in the existence of cases of electronic transaction information is "Investigator", in this case the Police investigator, where investigators are expected to be able to assist in the 
process of resolving cases of electronic transaction information violations. With the issuance of Law Number 19 of 2016 concerning Amendment to Law Number 11 of 2008 concerning Information and Electronic Transactions which regulates legal sanctions, as well as matters that are permitted, with the issuance of the law, investigators are expected to be able to implement case resolution processes against someone or more who has committed an electronic transaction information crime.

The effectiveness of the enactment of this law is very dependent on all levels of law enforcement, in this case all agencies that are directly involved, namely the National Police investigator and other law enforcers. That in the enforcement process the law of electronic transaction information, to make a criminal act that is suspected of occurring an investigation process is something that is very substance and has very basic interests. This is part of the police, especially police investigators because it is the investigator's function that can reveal the law enforcement of electronic transaction information. Besides that, the most important thing is the need for legal awareness from all levels of society to uphold the authority of the law and especially towards Law Number 19 of 2016 concerning Amendment to Law Number 11 of 2008 concerning Information and Electronic Transactions. So the role of investigators and the community is very important in helping the process of settlement of cases of electronic transaction information.

The importance of the investigation in revealing and making clear the suspicion of a criminal act of information on electronic transactions must be supported by supporting factors that can facilitate the investigation process. In terms of law enforcement information and electronic transactions have little difference with other criminal acts in general. Because in order to be able to support law enforcement, a lot of costs are needed in this case operational costs in presenting sanctions that participate in knowing the information and electronic transactions.

At the level of investigation and investigation of criminal cases of 
information and electronic transactions that occur in the Papua Regional Police in disclosing and enforcing the law in Law Number 19 Year 2016 concerning Amendments to Law Number 11 of 2008 concerning Information and Electronic Transactions, research still needs to be done, so the author chose the title "The Role of Police Investigators in Subscribing to Criminal Information and Electronic Transactions in Papua".

Based on the description above, it needs to be explained, among others:

1. What is the role of investigators in criminal acts of Information and Electronic Transactions?

2. A benchmark for investigators in detaining suspects?

3. The impact of not having detained suspects?

\section{METHOD}

The approach method used in this study is a normative juridical approach method, which is setting certain standards or norms for a phenomenon by reviewing secondary data. Normative legal research is library research, namely research on secondary data ${ }^{1}$. To examine the

1 Ronny Hanitijo Soemitro, (1990). Metodologi Penelitian Hukum dan Jurimetri, implementation of the legal principles of the regulations in the Criminal Procedure Code associated with misuse of authority by public officials in carrying out their powers. The legal material used in this study is primary legal material, namely Law Number 19 of 2016 concerning Amendment to Law Number 11 Year 2008 concerning Information and Electronic Transactions and Law Number 8 of 1981 concerning Criminal Procedure Law. The analysis uses qualitative methods, namely all legal materials are arranged systematically and analyzed qualitatively according to the problem.

\section{DISCUSSION}

\section{The Investigators}

To find out about the role of INP investigators in resolving Criminal Information and Electronic Transactions in Papua based on interrelated theories, the latter theory is a reaction or improvement from previous theories. Investigators are State police officers of the Republic of Indonesia or Civil Servants Officials who are given special

Cetakan Keempat, Jakarta, Ghalia Indonesia. p. 11. 
authority by law to conduct investigations. Investigation is a series of investigator's actions in terms of and according to the method stipulated in this law to search for and collect evidence with evidence that makes light about the criminal acts that occur and to find the suspect. The Auxiliary Investigator is a State Police Officer of the Republic of Indonesia who is given certain authority to carry out investigative duties as stipulated in the law.

Investigators are State Police Officers of the Republic of Indonesia who are authorized by this Act to be able to carry out investigations. The investigation were an investigator's action to find and find an event that was suspected of being a criminal offense to determine whether or not an investigation could be carried out according to the method stipulated in the law. Article 1 of the ITE Law includes among them the definition of Electronic Information. Here's the quote:

"Electronic Information is one or a group of electronic data, including but not limited to writing, voice, images, maps, designs, photos, electronic data interchange (EDI), electronic mail (electronic mail), telegram, telex, telecopy or the like, letters, signs, numbers, access codes, symbols, or performance that have meaning or can be understood by people who are able to understand it."

From the definition of Electronic Information above contains 3 meanings:

1. Electronic Information is one or a set of electronic data.

2. Electronic information has forms including writing, sound, images.

3. Electronic information has meaning or can be understood.

So, electronic information is electronic data that has form and meaning. Electronic information stored on hidden storage media. Electronic information can be identified and proven its existence from the form and meaning of Electronic Information. ${ }^{2}$

In addition to containing provisions regarding the implementation of electronic systems to support information and electronic transactions, the ITE Law also contains articles concerning, Prohibited Actions and Criminal Provisions. The act of being

\footnotetext{
${ }^{2}$ Politik Kompasiana. (2010). Quoted on date May 14, 2013, from http://politik.kompasiana.com/2010/03/02/un dang-undang-ite-dan-penggunaan-facebookdiindonesia.
} 
prohibited is contained in articles 2737, while the Criminal Provisions in article 45 - 52. Criminal cases can be in the form of imprisonment or fines. (Yunuz, Forumkami) $^{3}$. In this section, one example is related to actions that are prohibited in the ITE Law. With this example, it is expected that readers can take important lessons from the articles related to Prohibited Actions and Criminal Provisions.

\section{Purpose of Detention}

The role of law enforcement in the sense of function and its meaning is part of the concept of legal structure. There are 4 (four) functions of the legal system according to Friedman, namely: ${ }^{4}$

1. Social control function. According to Donald Black that all laws function as social control of the government.

2. Serves as a way of resolving disputes (dispute settlement) and conflict (conflict). Settlement of this dispute is usually for settlements which are in the form of small scale (micro) local conflicts. Conversely, macro-conflicts are called conflicts.

3 Yunuz, G. (2009) Binushacker. Quoted on date May 14, 2013, from http://www.binushacker.net/polemik-dankontroversiuu-ite.html.

${ }^{4}$ Siswanto Sunarso, (2004). Penegakan Hukum Psikotropika Dalam Kajian Sosiologi Hukum, Jakarta: PT. Rajagrafindo Persada, p. 69-70
3. Function retribution or social engineering function (retribution function and social engineering function). This function is for legal users to make planned social changes determined by the government.

4. Social maintenance function. This function is useful for enforcing the legal structure so that it continues to run in accordance with the rules of the game (rule of the game).

Based on the above, it can be said that the function of law enforcement is to actualize the legal rules so that they are in accordance with the aspirations of the law itself, namely to state human attitudes or behavior in accordance with the frame (workframe) stipulated by an Act law or law.

Criminal justice system in Indonesia can be seen from various mechanisms and systems as stipulated in Law Number 8 of 1981 concerning the Criminal Procedure Code. Institutions included in the system are: First, Investigators and investigators (Republic of Indonesia Police), as stated in Law No. 2 of 2002 concerning the police, as the caretaker of police functions, assisted by special police, civil servant investigators, and forms self-security. 
Second, the prosecutor is the Prosecutor's Office as stated in Law Number 16 of 2004 concerning the Prosecutor's Office, given additional authority to carry out investigations into criminal acts.

Special. Third, the Court, according to the Law concerning the main points of power of judges, is a judicial institution, separate from the executive institution, assisted by the Registrar and Staff, who are civil servants. Fourth, Eksekutor, Penitentiary Institution, manages correctional institutions in the managers of Detention Houses (Detention) and Custody of House of Confiscated Goods.

Based on the above, it can be said that the function of law enforcement is to actualize the legal rules so that they are in accordance with the aspirations of the law itself, namely to state human attitudes or behavior in accordance with the frame (workframe) stipulated by an Act law or law.

Criminal justice system in Indonesia can be seen from various mechanisms and systems as stipulated in Law Number 8 of 1981 concerning the Criminal Procedure Code.
Institutions included in the system are: First, Investigators and investigators (Republic of Indonesia Police), as stated in Law No. 2 of 2002 concerning the police, as the caretaker of police functions, assisted by special police, civil servant investigators, and forms self-security. Second, the prosecutor is the Prosecutor's Office as stated in Law Number 16 of 2004 concerning the Prosecutor's Office, given additional authority to carry out investigations into criminal acts.

Special. Third, the Court, according to the Law concerning the main points of power of judges, is a judicial institution, separate from the executive institution, assisted by the Registrar and Staff, who are civil servants. Fourth, Eksekutor, Penitentiary Institution, manages correctional institutions in the managers of Detention Houses (Detention) and Custody of House of Confiscated Goods. These four institutions are links that must work in a system to aim at the development objectives of the criminal law sector so that the community can live up to their rights and obligations and achieve and improve the guidance of 
each law enforcement officer in accordance with their respective functions and authorities. Then, in order to ensure the stability of law, justice and protection which is the protection of the dignity of human dignity, order and legal certainty, the four institutions must be in line in the process of law enforcement.

However, in the implementation it was not uncommon to find various deviations from the system which had been regulated so far. Criminal Justice System is a matter of Public service by the Government and is required to be aware of respect for human rights and privacy of citizens guaranteed by the 1945 Constitution. In this regard, to expand the scope of handling the Criminal Justice System, there should be no substitute the reference is to use the existing Criminal Code first. If this is related to legal development, the approach is not just a renewal of legal rules. Legal development aims to form or refer to the Indonesian legal system that is national (legal system). In the development, renewal or fostering of the Indonesian legal system that is of a national nature, it must be followed by the development, renewal or guidance of the substance of the legal system. It is the substance of the legal system that will determine the extent to which the Indonesian legal system with a national identity reflects new Indonesia and is able to serve the needs of the new Indonesia ${ }^{5}$. Thus in the development of the national legal system must include the development of the form and content of legislation. How to develop, update or guide the form and content of these laws and regulations are the substance of legislative policy. Legislative policy or legislation is political policy in compiling and referring the ideas of legislators (legislators) in the form of standard norms that are explicitly formulated in the form of national legislation, with the power of what is said by Austin, "The Command of the Sovereign". 6

In its development, the field of law shows a paradigmatic change. The weakness of natural law is because ideas or concepts about what are called laws are abstract. This will

\footnotetext{
5 Bagir Manan, (2005). Sistem Peradilan Berwibawa (Suatu Pencarian). Yogyakarta: FH UII Press, p. 157-158.

${ }^{6}$ Oko Setyono in Muladi (ed), (2005). Hak Asasi Manusia, Hakekat, Konsep dan Implikasinya dalam Perspektif Hukum dan Masyarakat. Bandung: PT. Refika Aditama, p. 123.
} 
lead to changes in orientation thinking by no longer emphasizing ideal and abstract values, but rather considering the real problems in community relations. This background ultimately gave birth to a positive law stream. ${ }^{7}$ Positive law teaches that positive law that regulates and applies is built on juridical norms that have been set by state authorities which there is a tendency to separate between wisdom and ethics and identify between justice and legality based on juridical norms set by state authorities. John Austin describes the law as a rule that is determined to fool intelligent beings by intelligent beings who have the power to defeat it. Therefore, the law must be separated from justice and instead legal truth must be based on good and bad ideas based on the highest provisions of power. ${ }^{8}$

Positivism is a school that begins to see its form clearly through the work of Agust Comte (1798-1857) with the title Cuorse de Philoshopie positive. Positivity only recognizes positive facts and phenomena that can

7 Wayan Prathiana, (1990). Pengantar Hukum Internasional, Bandung: Mandar Maju, p. 50

${ }^{8}$. Austin in M. Muslehudin, (1991). Filsafat Hukum Islam dan Pemikiran Oroentalis, Yogyakarta: PT. Tiara Wacana, p. 28 be observed with the objective relationship of these facts and the laws that determine them, leaving all investigations to be the highest causes or proposals.

Likewise, to be able to answer the problems in a research proposal it is positively implicated in that in any country all recognize the existence of an equal before the law or Equality before the law, such as the rule of low law used in Anglo Saxon countries that the rule of law covers:

1. Supermacy of law.

2. Equality before the law.

3. Constitruction based on human right. ${ }^{9}$

Theoretically, the president or the government has two positions, namely as one state organ and the state administration. As a state organ, the government acts for and on behalf of the state. While as a state administration, the government can act both in the regulation field (regelen) and in the field of services (besturen). The implementation of government tasks intended in this thesis is the administration of government duties as a state administration. Not as a country.

\footnotetext{
${ }^{9}$ Mariam Budiarjo, (1999). Dasar-dasar Ilmu Politik, Jakarta: Garamedia, p. 25
} 
In a state of law, every aspect of government action both in the field of regulation and in the field of service must be based on legislation or based on legality. This means that the government cannot carry out government actions without the basis of authority, the provision that every government action must be based on the principle of legality, is not fully applicable when a country adheres to conception of welfare state. Like Indonesia in the concept of the welfare state. The main task of the government is to provide services to the community. ${ }^{10}$

Scientifically, there are differences in the motion between making laws and problems that develop in society. Law making is slow, while problems are developing in the community. Law making has been slow, while social issues are proceeding rapidly. If every government action must always be based on the Law, then there will be many social problems that cannot be properly served. Therefore, in the concept of citizenship, government actions do not always have to be

\footnotetext{
${ }^{10}$ Prajudi, (1981). Hukum Administrasi Negara, Jakarta : Ghalia Indonesia, p. 27
}

based on the principle of legality. In certain cases the government can take action freely based on Ermessen's freies, namely the legitimate authority to intervene in social activities to carry out the tasks of administering public interests.

In the theory of criminal law known as the Remendium Ultimatum theorem or called the last suggestion in order to determine what actions will be criminalized (made as an offense or an act which if done will be faced with punishment). Whereas the step of criminalization itself is included in criminal policy theory, which one of the expert opinions of Peter G Hoefnagels defines as Criminal Policy is the rational organization of the control of crime by society which is interpreted as a rational effort of a State to combat crime. In the criminal policy, it was further explained that Criminal Policy as an asciense of responses, science of crime prevention, human policy of designating behavior as a crime and rational total of responses to crime. In addition there are requirements that determine which actions will be criminalized, namely that there is an agreement to criminalize and consider 
the cost and beneft principle, but it must also be considered not to overcriminalization. $^{11}$

To avoid over criminalization, it is reminded that the signs include:

1. The function of criminal law is fighting crime as a symptom of society

2. Criminal law and criminal law legislation must pay attention to the results of anthropological and sociological research.

3. Criminal is the most powerful tool that the State has to fight crime but criminal is not the only tool, so the midwives are separate, but always in combination with other social actions, especially in combination with preventive measures. (thinking of Von Liszt, Priens, Van Hammel founder of the Internationale Association Criminology). ${ }^{12}$

In connection with Hoenagles's thinking, it was emphasized again that it was important to consider various factors to criminalize in order to maintain the Ultimatum remendium argument and not occur over criminalization including: ${ }^{13}$

11 Barda Nawawi Arif, (1984). Bunga Rampai Kebijakan Hukum Pidana, Bandung: Alumni, p. 31-32

12 Ibid.

13 Muladi, (1995). Kapita Selekta Hukum Pidana, (Semarang : Badan Penerbit Iniversitas Diponegoro, p. 127-129
1. Don't use Emotional Criminal Law.

2. Do not use Criminal Law to convict an act that is not clearly a victim or loss.

3. Do not use Criminal Law, if the losses incurred by punishment will outweigh the losses from the criminal acts that will be formulated.

4. Do not use criminal law if it is not strongly supported by the community.

5. Don't use Criminal Law if its use is not effective.

6. Criminal law in certain matters must consider specifically the scale of the priority interests of regulation.

7. Criminal Law as a repressive means must be utilized simultaneously with prevention facilities.

In connection with the above, it is necessary to keep in mind the existence of the Ultimatum Remedium argument as the last means, which is related to the problem of how to be able to be convicted of an act committed intentionally or with negligence. In a speech by Minister Moderman, it was stated that to determine the aforementioned actions, it must be remembered that there were 2 basic principles. $^{14}$

14 Muladi dan Barda Nawawi Arief. (1984). Teori-teori dan Kebijakan Hukum Pidana, Bandung: Alumni, p 149. 
The basic principle is the first, the person who violates the law (this is an absolute condition of the theory of Condition sine qua non). Second, that the act violates the law and according to experience cannot be prevented by any means (of course by taking into account certain community conditions). The criminal threat must remain an Remedium Ultimatum. This does not mean that the criminal threat is abolished but must always consider the disadvantages of the criminal threat, and must not prevent undesirable events. This means that in order to achieve the goal of punishment, the state must properly provide its criminal sentence. But in this case the suspect was suspended for detention which could have a very dangerous impact and who had a threat of punishment over 5 years, should be detained but in this case the investigator did not detain him on the grounds that the suspect was cooperative and would not run away. But in practice suspects will be more free to eliminate existing evidence. Evidence removed which could be used as material to support the proceedings of criminal proceedings against suspects.

Remedium's ultimatum also means that criminal law has a purpose that is deviant or said to be more than a general goal which consists of maintaining order, calm, prosperity and peace in society without intentional suffering. It turns out that criminal law cannot avoid giving suffering when the law is violated and then must be enforced. For this reason, it must be thought deeply that the Remendium Ultimatum is considered, moreover in enforcing criminal law criminal procedure will also apply that is also broadly authorized to the Police and the prosecutor's office, so if it is not restricted the purpose of law enforcement will have a very adverse effect.

The Remendium ultimatum will also come in direct contact with the purpose of punishment and among others according to Cesare Beccaria Bonesana (1764) it is said that there are two things, namely for the purpose of special prevention and general prevention. The purpose of punishment is simply that the violator does not harm the community again 
and to frighten others into not doing so. According to Beccaria, the most important thing is the consequences that affect the community. Belief that it is impossible to escape from a crime that should be accepted, as well as the loss of profits generated by the crime. But Beccaria reminded once again that all transgressions are unnecessary because they mean abnormalities, Based on Article 21 point 1 of Law Number 8 of 1981 concerning Criminal Procedure Law states "Further detention orders or detention shall be carried out against a suspect or defendant who is suspected of committing a criminal offense based on sufficient evidence, in the event of a situation that raises concerns that the suspect or the defendant will flee, damage or eliminate evidence and/or repeat criminal acts".

The requirement for detention in Article 21 paragraph (1) of the Criminal Procedure Code (KUHAP) above is known by the requirement that subjective detention means the defendant can be detained if the investigator assesses or is worried that the suspect or defendant will escape, damage or eliminate evidence and / or repeat a crime.

In other words, if the investigator assesses the suspect/defendant will not flee, damage or eliminate evidence or repeat the crime, the suspect does not need to be detained.

While Article 21 paragraph (4) of the Criminal Procedure Code states, "Such detention can only be imposed on a suspect or defendant who commits a criminal act and/or attempts and provides assistance in the crime in the case of:

a. the crime is threatened with imprisonment of five years or more;

b. criminal acts as referred to in Article 282 paragraph (3), Article 296, Article 335 paragraph (1), Article 351 paragraph (1), Article 353 paragraph (1), Article 372, Article 378, Article 379 a, Article 453, Article 454, Article 455, Article 459, Article 480 and Article 506 of the Penal Code, Article 25 and Article 26 Rechtenordonnant (violations of Customs and Excise Ordinance, last amended by Staatsblad Year 1931 Number 471), Article 1, Article 2 and Article 4 of the Immigration Criminal Act (Law Number 8 Drt. 1955, State Gazette of 1955 Number 8), Article 36 paragraph (7), Article 41, Article 42, Article 43, Article 47 and Article 48 Law 
Number 9 of 1976 concerning Narcotics (State Gazette of 1976 Number 37, Supplement to State Gazette Number 3086)."

Article 21 paragraph (4) of the Criminal Procedure Code is known as objective detention requirements. This means that there is a clear measure stipulated in the law so that the suspect or defendant can be detained for example a crime allegedly committed by a suspect/defendant is punishable by imprisonment of five years or more, or the suspect/defendant commits a criminal offense as referred to in Article letter $b$ above.

Based on the description above, it can be understood that the name of the suspect/defendant is not required to be detained. Detention is carried out if it meets the detention requirements as stipulated in Article 21 paragraph (4) KUHAP (objective conditions) and fulfills the conditions as in Article 21 paragraph (1) KUHAP (subjective requirements).

\section{Determine of Suspect}

Based on Article 1 number 5 of Act Number 5 of 1986, the stipulation is a stipulation issued by a state administration body or official based on the applicable laws and regulations, which are concrete, individual and final which cause legal consequences for a person and legal entity. civil. The elements are:
a. Written determination
b. Registered by a state administration body or official
c. Contains constitutional law actions
d. Based on applicable laws and regulations
e. Concrete, individual and final

Based on Article 1 Number 14 of the Criminal Procedure Code (KUHAP) states that: "the suspect is a person because of his actions or circumstances, based on preliminary evidence it should be suspected of being a criminal offender".

The process of determining criminal acts and suspects is based on two evidences and the investigator's conviction that a criminal act or criminal act has occurred. The process or stages of examining a suspect carried out by the investigator must contain the following matters. ${ }^{15}$

a. The suspect has the right to be clearly informed of what is suspected of him.

15 Hari Sasangka, (2007). Penyidikan Penahanan Penuntutan Dan Praperadilan, Cetaka Pertama, Bandung: CV. .Mandar Maju. p. 100 
b. Suspects have the right to be accompanied by legal counsel.

c. The suspect has the right to present a witness who is profitable.

d. The suspect gives information without anyone's pressure.

e. The information of the suspect is recorded in detail by the investigator in the minutes.

Although the purpose of the Criminal Procedure Code in this case Pre-trial as a means of control and to protect human rights turns out in practice a sense of justice and legal certainty cannot be felt by the pretrial applicant, that the Case Examination of a pretrial application has been immediately declared dead without prior verification of the pretrial main problem.

The declaration was based on the consideration that the principal criminal case charged to the Petitioner had begun to be examined at a court hearing. One form of renewal of the substance of criminal law, especially formal criminal law and to uphold human rights, guarantees all citizens at the same time in law and government, it is necessary to strive to develop national law in order to create rule of law by conducting criminal law reform towards an integrated criminal justice system by placing law enforcers in their functions, duties and authorities.

But still must use and pay attention to the principle of equality before the law is the principle where there is an equality in law for each individual without an exception. Equality before the law means the same as the equation in the process of detention by the investigator. It is expressly stated that everyone has the same position before the law, meaning that everyone has the same position in prison. This is closely related to the norms and sense of justice in the law. Everyone has the same position before the law, meaning that everyone has the same position in the discretion of detention of a suspect by an investigator. In criminal procedural law there are several principles, while the connection with the discretion of detention of suspects is used as a principle, namely:

a. The same treatment for everyone before the law by not making a difference in treatment or discrimination, the principle is commonly called equality before the law;

b. Arrest, detention, searches and seizures are only carried 
out based on written orders by officials who are authorized by the Act and only in matters and in a manner regulated by law, or commonly called the principle of legality;

c. Anyone who is suspected, arrested, detained, prosecuted and/or faced before a court hearing, must be considered innocent until a court ruling states his guilt and obtains permanent legal force. This principle is usually called the principle of presumption of innocence or presumption of innocent; and

d. To someone who is arrested, detained, prosecuted or tried without reason based on law and/or because of an error regarding his person or the law applied must be compensated and rehabilitated from the level of investigation and law enforcement officials who intentionally or because of negligence caused the legal principle this is violated, prosecuted, convicted and or punished. ${ }^{16}$

In order for the law to develop and be able to relate to other nations as fellow legal communities, it is necessary to maintain and develop the principles and legal concepts that are

${ }^{16}$ Suryoto Sutarto, (1987). Seri Hukum Acara Pidana I, Semarang: Yayasan Cendikia Purna Darma, p. 13-14 generally adopted by mankind or universal legal principles. ${ }^{17}$

\section{The Damage of No Detention}

Justice must be built in accordance with the legal ideals (rechtidee) in the state of law (rechtsstaat), not the state of power (machtsstaat). Law functions as protection of human interests, law enforcement must pay attention to four elements, namely:
a. Legal certainty (rechtssicherkeit);
b. Benefits of law (zeweckmassigkeit);
c. Legal justice (gerechtigkeit); and
d. Legal
guarantee (doelmatigkeit). ${ }^{18}$

The impact of the absence of detention at the investigation level made the suspect remove evidence that had been uploaded in the suspect's Facebook status, even though the suspect was threatened with more than five years. Criminal Threats, namely article 27 paragraph (3) and (4) information laws and electronic transactions, with the threat

17 Mochtar Kusumaatmadja, (1997). Pemantapan Cita Hukum dan Asas-Asas Hukum Nasional di Indonesia Masa Kini dan di Masa Akan Datang, Majalah Pro Justitia Tahun XV No. 2 April. p 3-4

18 Ishaq, (2009). Dasar-Dasar Ilmu Hukum, Jakarta: Sinar Grafika. p. 43 
of criminal defamation and threats/scare.

In this case the Papua Regional Police Investigator did not detain the suspect despite the sentence of being more than five years in prison, arguing that the suspect was cooperative during the investigation at the investigation level.

\section{CONCLUSION}

From the description above, it can be drawn the conclusion that checking, to ensure that the provisions in the Criminal Procedure Code can be implemented properly, then the regulates the legal requirements for the detention of a suspect. The legal requirement for detention is directly related to the protection of individual rights which also functions as a means of monitoring horizontally. Investigation in the case of information and electronic transactions is a method of seeking justice for detention of suspects is still far from what was expected, because the police investigators still lacked the place to detain suspects during POLRI detention so that they could override what was the basis of consideration and evidence there is.
However, there is one case of electronic information and transactions submitted in 2017 with the threat of a sentence of more than five years for detention. Here it can be noted that the investigator overrides what will happen to the reporter or victim witness. It can be noted that investigators have considerations stating that the suspect will not escape and the suspect is still cooperative.

\section{BIBLIOGRAPHY}

Arif, Barda Nawawi. (1984), Bunga Rampai Kebijakan Hukum Pidana, Bandung: Alumni.

Austin J. in Muslehudin, M. (1991). Filsafat Hukum Islam dan Pemikiran Oroentalis, Yogyakarta: PT. Tiara Wacana.

Budiarjo, Mariam. (1999). Dasardasar Ilmu Politik, Jakarta : Garamedia.

Huibers, Theo. (1990). Filsafat Hukum Dalam Lintasan Sejarah, Yogyakarta: Kanisius.

Ishaq. (2009). Dasar-Dasar Ilmu Hukum, Jakarta: Sinar Grafika.

Manan, Bagir. (2005), Sistem Peradilan Berwibawa (Suatu Pencarian). Yogyakarta: FH UII Press.

Muladi, (1995). Kapita Selekta Hukum Pidana, Semarang: Badan Penerbit Universitas Diponegoro. and Arief, Barda Nawawi. (1984). Teori-teori dan 
Kebijakan Hukum Pidana, Bandung: Alumni.

Prajudi, (1981), Hukum Administrasi Negara, Jakarta: Ghalia Indonesia.

Prathiana, Wayan. (1990). Pengantar Hukum Internasional, Bandung: Mandar Maju.

Setyono Oko in Muladi (Ed), (2005.), Hak Asasi Manusia, Hakekat, Konsep dan Implikasinya dalam Perspektif Hukum dan Masyarakat, Bandung: PT. Refika Aditama.

Soemitro, Ronny Hanitijo. (1990). Metodologi Penelitian Hukum dan Jurimetri, Cetakan Keempat, Jakarta: Ghalia Indonesia.

Sunarso, Siswanto. (2004). Penegakan Hukum Psikotropika Dalam Kajian Sosiologi Hukum, Jakarta: PT. Rajagrafindo Persada.

Sutarto, Suryoto. (1987). Seri Hukum Acara Pidana I, Semarang, Yayasan Cendikia Purna Darma.

\section{Article :}

Kusumaatmadja, Mochtar. (1997). Pemantapan Cita Hukum dan Asas-Asas Hukum Nasional di Indonesia Masa Kini dan di Masa Akan Datang, Majalah Pro Justitia Tahun XV No. 2 April. p. 3-4
Politik Kompasiana. (2010, March 02). Quoted on date May 14, 2013, from http://politik.kompasiana.com/2 010/03/02/undang-undang-itedan-penggunaan-facebookdiindonesia.

Yunuz, G. (2009). Binushacker. Quoted on date May 14, 2013, from

http://www.binushacker.net/pol emik-dan-kontroversiuuite.html.

\section{Rules :}

Undang-Undang Dasar Negara Republik Indonesia Tahun 1945 Amandemen Keempat.

Kitab Undang-Undang Hukum Pidana.

Undang-Undang Nomor 8 Tahun 1981 tentang Kitab UndangUndang Hukum Acara Pidana (Lembaran Negara Republik Indonesia Tahun 1981 Nomor 76, Tambahan Lembaran Negara Republik Indonesia Nomor 3209).

Undang-Undang Nomor 39 Tahun 1999 tentang Hak Asasi Manusia (Lembaran Negara Republik Indonesia Tahun 1999 Nomor 165, Tambahan Lembaran Negara Republik Indonesia Nomor 3886).

Undang-Undang Nomor 19 Tahun 2016 tentang Perubahan Undang-undang Nomor 11 Tahun 2008 Tentang Informasi dan Transaksi Elektronik. 